DOI: https://doi.org/10.34069/AI/2021.48.12.6

How to Cite:

Popovych, I., Semenov, O., Skliaruk, A., Sotnikova, K., \& Semenova, N. (2021). Research of the dominant psycho-emotional states of university lecturers during the progression of the COVID-19 pandemic. Amazonia Investiga, 10(48), 52-62. https://doi.org/10.34069/AI/2021.48.12.6

\title{
Research of the dominant psycho-emotional states of university lecturers during the progression of the COVID-19 pandemic
}

\section{Дослідження домінуючих психоемоційних станів викладачів закладів вищої освіти під час прогресування пандемії COVID-19}

Received: September 15, 2021

Accepted: October 20, 2021

\author{
Written by: \\ Ihor Popovych ${ }^{17}$ \\ https://orcid.org/0000-0002-1663-111X \\ Oleksandr Semenov ${ }^{18}$ \\ https://orcid.org/0000-0002-3839-4725 \\ Anastasia Skliaruk ${ }^{19}$ \\ https://orcid.org/0000-0001-8373-2351 \\ Kateryna Sotnikova ${ }^{20}$ \\ https://orcid.org/0000-0001-9553-4897 \\ Nataliia Semenova $^{21}$ \\ https://orcid.org/0000-0002-5247-7439
}

\begin{abstract}
The aim of the article was empirical research of the dominant psycho-emotional states of university lecturers during the progression of the COVID-19 pandemic. The article is devoted to an empirical study of the factor structure and the prevailing correlations between the psychoemotional states of the respondents. Valid empirical methods with standardized questionnaires were used: the dominant coping strategy research method, the test of differentiation of emotional states, and the anxiety research method. The study's empirical picture constructed. Psycho-emotional states were qualitatively interpreted, states were distinguished, and semantic psychological parameters were defined. The factor structure of the dominant psycho-emotional states of university lecturers was determined. The psychoemotional state of F1 "Isolated activity", which had the most intercorrelations and had the most significant $(p \leq .01) \quad$ correlation with F4 "Pragmatic avoidance" (.344), was found to have
\end{abstract}

\section{Анотація}

Метою статті було емпіричне дослідження домінуючих психоемоційних станів викладачів закладів вищої освіти під час прогресування пандемії COVID-19. Стаття присвячена емпіричному дослідженню факторної структури та превалюючих взаємозв'язків психоемоційних станів респонденів. Застосовано валідні емпіричні методи зі стандартизованими анкетами: методика дослідження домінуючих копінгстратегій, тест диференціювання емоційних станів і методика дослідження тривожності. Побудовано емпіричну картину дослідження. Якісно інтерпретовано психоемоційні стани, виокремлено один стан від іншого, окреслено змістові психологічні параметри. Визначено факторну структуру домінуючих психоемоційних станів викладачів закладів вищої освіти. Встановлено, що найбільше факторне навантаження отримав психоемоційний стан F1 “ізольована активність”, який має найбільше

\footnotetext{
${ }^{17}$ Doctor of Psychological Sciences, Full Professor of the Department of Psychology, Kherson State University, Kherson, Ukraine.

${ }^{18}$ Doctor of Pedagogical Sciences, Full Professor of the Department of General Pedagogy and Preschool Education, Volyn National University named after Lesia Ukrainka, Lutsk, Ukraine.

${ }^{19}$ Doctor of Psychological Sciences, Associate Professor of the Department of Practical Psychology, Classical Private University, Zaporizhzhia, Ukraine.

${ }^{20}$ Post-graduate student of the Department of Practical Psychology and Social Work, Volodymyr Dahl East Ukrainian National University, Severodonetsk, Ukraine.

${ }^{21}$ Candidate of Pedagogical Sciences, Associate Professor of Department of Pedagogy, Volyn National University named after Lesia Ukrainka, Lutsk, Ukraine.
} 


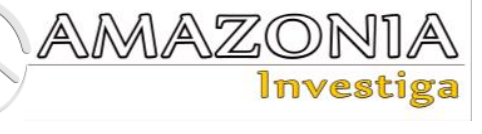

the greatest factor load. It was empirically established and theoretically substantiated that the structure, variables, and interdependence of the factors of dominant psycho-emotional states were important components in solving issues of lecturers' professional activity. It was noted that the findings may be useful for university administrations and pedagogical psychology researchers.

Key words: mental state, pedagogical activity, educational process, psychology of lecturer.

\section{Introduction}

Our entire planet has been overwhelmed by the COVID-19 pandemic. It is difficult to imagine a person or group of people who are unaware of the progression of the COVID-19 pandemic in a civilized world and the terrible consequences that civilization has suffered and continues to suffer. Every aspect of human existence has been confronted with a challenge that has forced them to orient themselves and concentrate their efforts on overcoming it. In addition, the new socioeconomic reality that has emerged has created new opportunities for humanity. The educational sphere is not an exception, but perhaps the flagship of using such opportunities and introducing innovations. The psychoemotional load that employees of all levels of education are forced to bear, motivates us to focus on this area of research.

An enormous number of researchers are scientifically interested in the study of problems in the psychological-emotional sphere of personality. That sought, first and foremost, to identify patterns and determinants of core psychological education in human activity (Izard, 2007; Prokhorov et al., 2015b; Shevchenko et al., 2020b). Our research interest is in the study of the psycho-emotional load received by university lecturer in the context of their professional activities in a quarantined situation. Educators' professional activities are being influenced by current socio-cultural changes and challenges. Since the psychoemotional state cannot exist apart from activity, the intercorrelations, structure, and deep essence of this psychological phenomenon can only be clarified through current activity.

There are studies in the scientific literature that investigate an individual's mental state in various areas of their activities, such as education (Halian взаємозв'язків, i має найбільш значуще ( $\leq \leq .01)$ співвідношення 3 F4 "прагматичне уникнення" (.344). Емпірично встановлено і теоретично обгрунтовано, що структура, змінні i взаємозалежність факторів домінуючих психоемоційних станів $\epsilon$ важливими складовими у вирішенні завдань професійної діяльності викладачів. Зазначено, що результати можуть бути корисні адміністраціям університетів, дослідникам педагогічної психології.

Ключові слова: психічний стан, педагогічна діяльність, освітній процес, психологія викладача.

et al., 2020b; Prokhorov et al., 2015b), sports, marine, and other areas (Nosov et al., 2020b; Shevchenko et al., 2020a). Researchers discovered and validated a significant list of psychological parameters (Halian et al., 2020a), provided an interpretation of semantic features (Blynova et al., 2020a), and proposed appropriate psychodiagnostic tools (Blynova et al., 2020c). Psychological semantic parameters of psychoemotional states, as well as motivational states, are described in a variety of sources as structural components of an integrated multifaceted phenomenon (Krupnyk \& Tkalenko, 2019; Popovych et al., 2020c; Pinkovetskaia et al., 2020). Such an interpretation results in the multifaceted content of the studied phenomenon's categoricalconceptual content as well as uncertainty in the system of psychological concepts. At the same time, we should state that the substantiation of a significant list of psychological semantic parameters in the known concepts of dimensions of professional activity (Blynova et al., 2020d; Popovych et al., 2021a), professional development, and personality development (Blynova et al., 2020d; Popovych et al., 2021a) (Tsiuniak et al., 2020) were found.

According to V. Prokhorov et al. (2015a), mental state is a general functional level of mental activity that is affected by a person's professional activity or even inactivity, as well as their individual psychological characteristics. Mental states can be stable, changeable, situational, short- and long-term, and personal, with a variety of classification characteristics (Prokhorov et al., 2015a).

In summary, dominant psychoemotional states are mental states that combine mental processes with features. Dominant psycho-emotional states 
have the potential to be important regulators of successful activity. In order to effectively organize educational activities, university's administration must understand the structure and psychological content of lecturers' psychoemotional states. The type of dominant psychoemotional state has a direct impact on the educational activity's success. We believe that the understanding of the semantic parameters of psycho-emotional states by the educational institution administrators will allow them to operationalize the solution to production problems related to educators, which can have a significant impact on student training. Researchers discovered that mental states of expectation have an impact on the functioning of mental processes and have the potential to reoccur. Systemic repetition contributes to the stability of mental processes, which are transformed into personality traits as a result of activity (Popovych et al., 2021b). Internality, externality, activity, passivity, openness, and closeness are all characteristics that accompany the process of professional activity (Popovych et al., 2021b). Mental states, according to C. Izard (2007), are closely related to mental activity and can manifest as mental stress. Mental states have the ability to adapt to person's needs and desires, utilizing their capabilities and resources to ensure its development in specific living conditions (Prokhorov et al., 2015b).

We define an university lecturer's dominant psycho-emotional state as the integrated set of available characteristics that affect the outcome of their professional activities: the implementation of educational, upbringing, teaching, and research tasks.

Theoretical analysis of the scientific literature has revealed that the place and role of lecturer's dominant psycho-emotional states in universities are poorly understood. Regardless of its importance and relevance, the outlined problem requires empirical research and substantiation in a new dimension, as determined by the realities of today's COVID-19 pandemic.

Hypothesis. We suspect that the framework, parameters, and interrelatedness of the variables impacting university lecturers' dominant psychoemotional states are crucial aspects of their professional activity.

The aim of the article is to theoretically analyze and empirically study the dominant psychoemotional states of university lecturers during the progression of the COVID-19 pandemic; an empirical study of the factor structure and the prevailing correlations between psychoemotional states of respondents.

\section{Materials and methods}

The interpretation of the dominant psychoemotional state, as an extremely important psychological content parameter of the emotional-volitional sphere of personality, represented as the study's methodological starting point. A person's psycho-emotional state is a reflection of how they organize their mental and emotional activity. It reflects a person's readiness to perform activities due to their semantic features and attitudes. Mental states are the stable integration of all of person's mental manifestations during any of interactions with the environment. The mental states are reflected in the organization of the psyche. The psyche is a brain function that has the ability to reflect reality. At the same time, our empirical study of dominant psycho-emotional states requires careful research into the educational professional activities of lecturers. These views are methodologically confirmed in the study of cognitive states during intellectual activity of students through the structure of the state of interest / mental stress (Prokhorov et al., 2015b), in the study of mental state of expectation in educational and professional activities (Popovych et al., 2021b), in studies of the mental state of chronic fatigue, which impairs physical performance (Marcora et al., 2009), also in studies of other aspects of people's performance (Nosov et al., 2020a ; Zinchenko et al., 2019; 2020). The study's empirical picture is built around the investigation of social expectations as a mental state of person (Popovych et al., 2021b). Participants. Lecturers from the following universities participated in the study: Kherson State University (Kherson, Ukraine) $(n=12)$; Classical Private University (Zaporizhzhia, Ukraine $\quad(n=23)$; Volodymyr Dahl East Ukrainian National University (Severodonetsk, Ukraine) $(n=19)$. The age of the respondents ranged from 26 to 67 years old. Respondents were selected randomly with different family and social status and professional experience. They represented the social sciences, as well as the technical, physical, and mathematical sciences. The total number of participants was 54 people (45 female respondents, which represented $83.33 \%$, and 9 male respondents, which represented $16.67 \%$ ). The respondents' average age was 52.12 years. The empirical study was organized and conducted in compliance with all ethical requirements of the Committee on the Rights of Experiments, which are stated in the Declaration of Helsinki (2013). 


\section{$\frac{\text { AMAZONDA }}{\text { Dovestiga }}$}

Organization of Research. In 2020, and specifically from March to December, standardized questionnaire tests, which measured the studied variables of respondents were used. The coping test "Way of Coping Questionare" ("WCQ") was used (Lazarus \& Folkman, 1984). The test was adapted by T. Kriukova and Ye. Kuftiak (2007). The following psychodiagnostic variables, which are coping strategies in an empirical situation, were measured: self-control, confrontation, pursuing support networks, distantiating, drawing up plans to resolve issues, accepting responsibility, avoidance, and positive reestimation. The semantic unipolar differentiated four-point scale was used. Scale values range from 0 (never) to 3 (often). The parameter of internal consistency $\alpha$ Cronbach was $\alpha=.812$. The "Differential Emotions Scale IV-A" method ("DES, version IV-A") (Izard, 2007) was used to measure the respondents' emotional states. The method differentiates ten emotional states: anger; disgust; interest; joy; surprise; fear; shame; grief; contempt; guilt. Also, the eleventh parameter is measured - the coefficient of self-feeling. The semantic unipolar differentiated four-point scale was used. The value of the scale - from 1 (not suitable at all) to 4 (absolutely true). The parameter of internal consistency $\alpha$-Cronbach was $\alpha=.865$. Scale of self-assessment of reactive (situational) and personal anxiety ("SSRPA") was the next psychodiagnostic method (Spielberger, 1971). Yu. Khanin (1976) adapted the questionnaire. Two parameters relevant to the context of our study were taken: self-assessment of anxiety, which reflects situational reactive anxiety, and self-assessment, which reflects personal anxiety. The semantic unipolar differentiated four-point scale was used. The value of the scale is from 1 (no, never) to 4 (quite correct). The parameter of internal consistency $\alpha$ Cronbach was $\alpha=.789$. It is stated that the reliability indicators of the applied $\alpha$-Cronbach methods and tests are within the medium (.8) and high levels (.9).

Statistical Analysis. The statistical software package "SPSS" v. 24.0 was used to provide statistical maintenance. Correlation relationships were determined using the Spearman correlation coefficient $\left(\mathrm{r}_{\mathrm{s}}\right)$. ANOVA factor analysis was used, as well as the Promax main component method of oblique rotation. The primary frequency characteristics have been established. Significant reliability parameters were recorded at a level not lower than $\mathrm{p} \leq .05$.

\section{Results}

The descriptive frequency characteristics of psychological semantic parameters were determined using selected psychodiagnostic methods. The obtained psychological semantic parameter results were determined by using the minimum (Min), maximum (Max), arithmetic mean (M), and standard deviation scales (SD).

Table 1.

The frequency characteristics of psychological content parameters according to "WCQ" ( $n=54)$

\begin{tabular}{lllll}
\hline Scale & Min & Max & M & SD \\
\hline Self-control & 16.33 & 83.67 & 70.45 & 15.07 \\
Confrontation & 16.33 & 74.67 & 46.11 & 19.11 \\
Pursuing support networks, & 12.25 & 70.67 & 41.12 & 12.31 \\
Distancing & 12.25 & 82.67 & 48.91 & 14.15 \\
Drawing up plans to resolve & 12.25 & 82.67 & 65.09 & 21.03 \\
issues & 16.33 & 81.43 & 53.39 & 18.98 \\
Acceptance of responsibility & 17.00 & 82.67 & 53.37 & 17.98 \\
Avoidance & 12.25 & 71.33 & 47.29 & 16.90 \\
Positive Reestimation & & & &
\end{tabular}

Source: Personal elaboration, 2021.

Note: $\mathrm{M}$ - arithmetic mean; SD - mean-square deviation.

Table 2 demonstrates the frequency characteristics according to the method "DES, version IV-A" (Izard, 2007). 
Table 2.

The frequency characteristics of psychological semantic parameters according to "DES, version IV-A" $(n=54)$

\begin{tabular}{lllll}
\hline Scale & Min & Max & M & SD \\
\hline Anger & 3.0 & 10.0 & 6.56 & 1.78 \\
Disgust & 3.0 & 6.0 & 3.21 & .89 \\
Interest & 3.0 & 11.0 & 7.12 & 2.78 \\
Joy & 3.0 & 11.0 & 10.11 & 2.44 \\
Surprise & 3.0 & 13.0 & 6.67 & 2.55 \\
Fear & 3.0 & 9.0 & 4.12 & 1.68 \\
Shame & 3.0 & 9.0 & 4.44 & 1.56 \\
Grief & 3.0 & 6.0 & 3.45 & .77 \\
Contempt & 3.0 & 10.0 & 3.57 & 1.79 \\
Guilt & 3.0 & 8.0 & 3.78 & 1.56 \\
Coefficient of Self-feeling & 0.8 & 2.8 & 1.89 & .89 \\
\hline
\end{tabular}

Source: Personal elaboration, 2021.

Note: $\mathrm{M}$ - arithmetic mean; SD - mean-square deviation.

Table 3 demonstrates the frequency characteristics of the questionnaire ("SSRPA") (Spielberger, 1971).

Table 3.

The frequency characteristics of psychological semantic parameters according to "SSRPA" (Spielberger, 1971) $(n=54)$

\begin{tabular}{lllll}
\hline Scale & Min & Max & M & SD \\
\hline $\begin{array}{l}\text { Self-assessment of Situational } \\
\text { Reactive Anxiety }\end{array}$ & 9.0 & 52.0 & 37.89 & 8.89 \\
$\begin{array}{l}\text { Self-Assessment of Personal } \\
\text { Anxiety }\end{array}$ & 11.00 & 57.0 & 38.97 & 9.78 \\
\hline
\end{tabular}

Source: Personal elaboration, 2021.

Note: $\mathrm{M}$ - arithmetic mean; SD - mean-square deviation.

The study's empirical picture was a complex of twenty-one semantic psychological parameters. These parameters were methodologically sufficient and relevantly reproduce the subject features of the study of respondents' dominant psycho-emotional states. In the context of our study, the names of the scales were relevant and appropriate.
We presently moved on to the matrix of correlation variables, which was determined by the main component method with the Promax oblique rotation. Seven factors with loads greater than one are identified, and the sum of the variances of the variables are within $62.536 \%$ (Tabl. 4).

Table 4.

The factor load matrix (seven factors, twenty-one variables)

\begin{tabular}{|c|c|c|c|c|c|c|c|}
\hline Scale & F1 & F2 & F3 & F4 & F5 & F6 & F7 \\
\hline Self-control & .502 & -.312 & .407 & & & & \\
\hline Confrontation & & .179 & .649 & -.532 & & & \\
\hline $\begin{array}{l}\text { Seeking Social } \\
\text { Support }\end{array}$ & -.456 & & -.512 & & -.356 & & \\
\hline Distancing & .541 & -.345 & .439 & & & & \\
\hline $\begin{array}{l}\text { Planning to Solve a } \\
\text { Problem }\end{array}$ & .371 & & & & .378 & .509 & \\
\hline $\begin{array}{l}\text { Acceptance of } \\
\text { responsibility }\end{array}$ & -.712 & -.378 & .376 & & & & \\
\hline Avoidance & & & & .589 & & -.594 & .295 \\
\hline Positive Reestimation & & .577 & & -.409 & & & .323 \\
\hline Anger & .774 & & -.019 & .071 & & & \\
\hline
\end{tabular}




\begin{tabular}{|c|c|c|c|c|c|c|c|}
\hline Disgust & .751 & & -.041 & & .043 & & \\
\hline Interest & & .652 & .021 & & & & \\
\hline Joy & & & & .076 & .583 & & \\
\hline Surprise & & .553 & & & . 341 & -.127 & \\
\hline Fear & .884 & & & .076 & & & \\
\hline Shame & & -.056 & .545 & .069 & & & \\
\hline Grief & .859 & & & & .034 & & -.151 \\
\hline Contempt & .732 & & & & .353 & -.091 & \\
\hline Guilt & & 487 & .506 & & & & \\
\hline $\begin{array}{l}\text { Coefficient of Self- } \\
\text { feeling }\end{array}$ & .760 & & -.019 & & & .257 & \\
\hline $\begin{array}{l}\text { Self-assessment of } \\
\text { Situational Reactive } \\
\text { Anxiety }\end{array}$ & .588 & & & & & -.195 & -.215 \\
\hline $\begin{array}{l}\text { Self-Assessment of } \\
\text { Personal Anxiety }\end{array}$ & .312 & & .563 & & & & -.524 \\
\hline Dispersion, \% & 21.418 & 10.175 & 9.938 & 7.160 & 6.412 & 5.012 & 2.421 \\
\hline$\sum$ dispersion, \% & 21.418 & 31.593 & 41.531 & 48.691 & 55.103 & 60.115 & 62.536 \\
\hline Value & 9.502 & 4.514 & 4.409 & 3.177 & 2.8445 & 2.223 & 1.074 \\
\hline
\end{tabular}

Source: Personal elaboration, 2021.

Note: Loads of significant variables are highlighted in bold. The principal component method is a method for selecting factors.

F1 "Isolated activity" showed the dependence of the dominant psycho-emotional state of the lecturer, who, in connection with the quarantine distanced themselves, had a significant self-assessment of situational reactive anxiety. This psycho-emotional state was accompanied by pessimistic emotions such as anger, disgust, fear, grief, and contempt. Accordingly, the coefficient of self-feeling that loaded this mental state had a significant level (.760). The action of this factor outlined the psychoemotional state of isolated activity, without the desire to take responsibility for the tasks of professional activity.

F2 "Inquisitive reestimation" was a desire to rationalize the situation of uncertainty, an opportunity to find the positive in the current situation. Accompanied by emotions of interest and surprise, characterized by a reluctance to take responsibility and control the situation.

F3 "Destructive isolation" was a reflection of confrontation and the lack of desire to seek social support in the current situation. Respondents of this dominant psycho-emotional state were overwhelmed by emotions of shame and guilt.

F4 "Pragmatic avoidance" was planning to avoid a problem, which was partly not accompanied by a positive reevaluation of the real situation. This dominant psycho-emotional state was accompanied by the immaturity of emotions, a kind of indifference, without a deep experience of the real social situation.
F5 "Exaltation" consists of a variable, the content of which was a reflection of joy, accompanied by the activity of the respondent, without seeking social support. It seemed that such respondents were detached from reality. They rejoiced in changes in social reality without worrying about the consequences and losses of quarantine.

F6 "Constructive activity" was characterized by the desire of the subject to plan problem solving, to take responsibility. Such respondents strived to perform current tasks at the appropriate professional level. Their psycho-emotional state had a positive direction.

F7 "Optimistic evaluation" showed that respondents didn't have personal anxiety (-.524), were able to rationalize and positively reevaluate social reality, avoid responsibility, and psychoemotional state was accompanied by a desire to perform tasks responsibly. Such respondents were sure that everything will be fine.

The other factors were not included in our structure, because they had a load that is outside of the total variance, ie was less than .994 .

We conclude the presence of seven main factors $(62.536 \%)$, which determined the structure of psycho-emotional states of university lecturers (Fig. 1). 


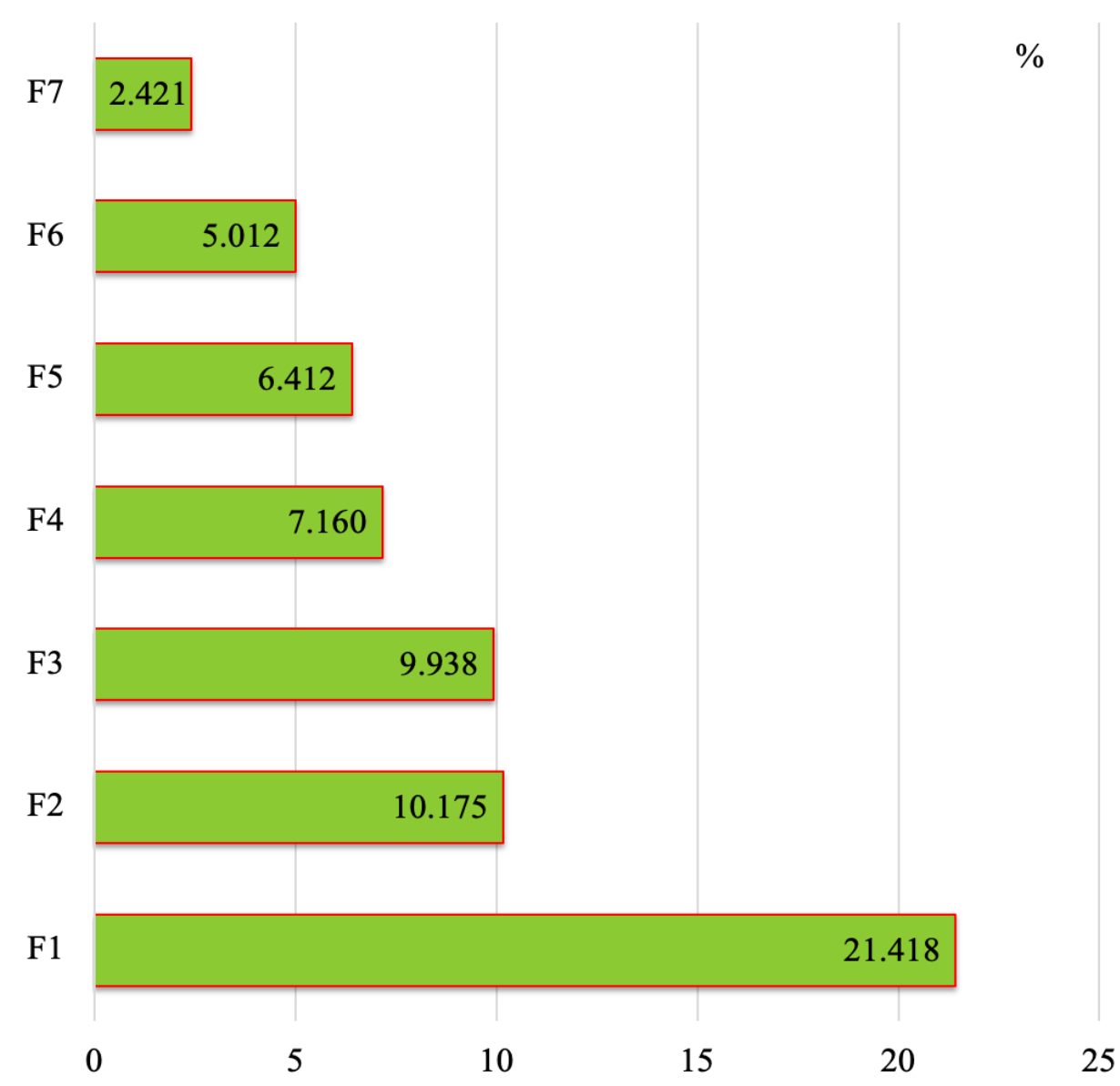

Figure 1.

The factor structure of university lecturers' psycho-emotional states.

Source: Personal elaboration, 2021.

Table 5 demonstrates the interdependence of the factors that determined the structure of university lecturers' dominant psycho-emotional states.
The strongest correlations between the established variables were investigated.

Table 5.

The matrix of correlations of structural components of university lecturers' dominant psycho-emotional states.

\begin{tabular}{llllllll}
\hline Factor & F1 & F2 & F3 & F4 & F5 & F6 & F7 \\
\hline F1 & 1.000 & -.036 & $-.113 *$ & $.356^{* *}$ & -.013 & $.145^{* *}$ & $.130^{* *}$ \\
F2 & -.036 & 1.000 & -.011 & -.021 & .021 & -.041 & $-.163 * *$ \\
F3 & $-.113^{*}$ & -.011 & 1.000 & .031 & .039 & -.006 & -.025 \\
F4 & $.356 * *$ & -.021 & .031 & 1.000 & $-.179 * *$ & $.109 *$ & .038 \\
F5 & -.013 & .021 & .039 & $-.179 * *$ & 1.000 & $-.269 * *$ & $-.203 * *$ \\
F6 & $.145^{* *}$ & -.041 & -.006 & $.109 *$ & $-.269 * *$ & 1.000 & $.183 * *$ \\
F7 & $.130 * *$ & $-.163 * *$ & -.025 & .038 & $-.203 * *$ & $.183 * *$ & 1.000 \\
\hline
\end{tabular}

Source: Personal elaboration, 2021.

Note: Method of factors selection: method of main components; rotation method: Promax with Kaiser normalization; $*$ - statistically significant at $\mathrm{p} \leq .05 ; * *-$ statistically significant at $\mathrm{p} \leq .01$.

The most significant positive relationship $(\mathrm{p} \leq .01)$ was the ratio of $\mathrm{F} 1$ "Isolated activity" and F4 "Pragmatic avoidance" (.344), and the most significant positive relationship was F5 and F6 (.269). F1 "Isolated Activity", F6 "Constructive Activity" and F7 "Optimistic Evaluation" had the 


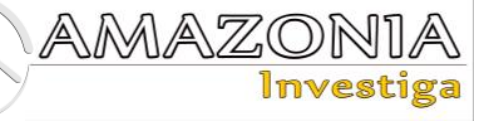

largest number of significant relationships with all factors - four. Thus, isolated activity is the most important component in contexts of psychometric properties of psycho-emotional state of mind of university lecturers. The most dependent factors in the structure were: F1, F6, and F7. The most independent factors of the dominant psycho-emotional states were F2 and F3.

\section{Discussion}

There are almost no empirical studies in the scientific literature on the dominant psychoemotional states in lecturers' professional activities, except the study of this scientific problem, which is organized and conducted during the progression of the COVID-19 pandemic. Professional formation and personality development have been considered by researchers in the context of solving, in their opinion, more important tasks related to professional identity (Blynova et al., 2020b; Popovych et al., 2020b), value orientations (Popovych et al., 2021c), critical thinking (Arbeláez-Campillo et al., 2020), and others. The present and the organization of the educational process during quarantine, encourage to focus on the study of the dominant psycho-emotional states of university lecturers. Organized research has a common starting point in scientific and methodological terms with the study of cognitive mental states in the process of intellectual activity of students (Prokhorov et al., 2015a; 2015b). Furthermore, the scientific facts we discovered are supported by research on the correlation between existential anxiety and the reason for the existence of personality (Popovych et al., 2020a). It is appropriate to point to the current study of existential semantic features during quarantine of feelings of anxiety and worry and the mediating role of existential anxiety and life satisfaction. This study qualitatively reflected the current situation regarding post-traumatic stress disorder symptoms and post-traumatic coping (Tomaszek \& Muchacka-Cymerman, 2020).

The empirical data obtained by us, as well as the established factor structure of psychoemotional states, are related to a number of other studies conducted during the progression of the COVID19 pandemic. In these dimensions, the researchers identified the features of the dimension control of the respondents' attitude, which in the context of activity/passivity and isolation/openness' dichotomous measurements, didn't contradict the current data. (Khmiliar et al., 2020). A. Hudimova (2021) identified social media users' behavioral patterns in the context of social well-being. It is worth noting that the contours of our proposed dominant psychoemotional states are similar to the substantiated patterns of behavior of social media users (Hudimova et al., 2021). We contend that the majority of professional employment for lecturers during quarantine is reduced to work on social media and other online applications. The dominant psycho-emotional states of educators acquire resilience, stabilize, receive formation and development during professional activity. The studied states are able to transform into personality traits, which in turn can affect the content of lecturer's professional activities. Transformation of psycho-emotional states is a technological component of professional prosperity, acme. At the same time, the transformation of psycho-emotional states can lead to negative consequences - psychoemotional burnout, frustration, occupational crises, and deformities. Thus, the dominance of any psycho-emotional state has an impact on the semantic features of professional activity and the results of respondents. The most effective are F6 "Constructive Activity" and F7 "Optimistic Evaluation", which are able to maintain mental health and ensure the highest results. The dominant psycho-emotional states F3 "Destructive Isolation" and F5 "Exaltation" are the most dangerous. F3 has the fewest correlations with a pronounced coping strategy and no desire to seek social support. The obtained empirical data and theoretical substantiation support our hypothesis that the structure, variables, and interdependence of the factors influencing the dominant psycho-emotional states of university lecturers are important components of their professional activity. The operationalization of research results will assist in the effective organization of educators' professional activities.

\section{Conclusions}

1. We state that the deep essence of university lecturers' dominant psycho-emotional states should be studied in the context of professional activity, during the performance of educational tasks.

2. The empirical results show that the dominant psycho-emotional states in professional activity are an extremely complicated complex formation. The chosen set of psychodiagnostic valid techniques and statistical data processing methods enabled us to qualitatively interpret psychoemotional states, differentiate one state from another, and substantiate semantic features. 
3. The framework of the dominant mental states, which consists of seven key trends, was determined using ANOVA factor analysis $(62.536 \%)$. It is established that the most crucial element in the structure and function organization of the dominant lecturers' psycho-emotional state of mind is F1 "Isolated activity". The strongest significant positive correlation $(\mathrm{p} \leq .01)$ has the ratio F1 and F4 (.344).

4. It is substantiated that the structure, variables, and interdependence of the factors of the dominant psycho-emotional states of university lecturers are important components of their professional activity. The operationalization of research results will contribute to organizing professional activity more effectively.

5. It is generalized that the results of the research may be useful to university administrations, educators, as well as researchers in the field of pedagogical psychology, psychology of personality's professional activity.

\section{Bibliographic references}

Arbeláez-Campillo, D., Tatsiy, V., RojasBahamón, M., \& Danilyan, O. (2020). Contributions of critical thinking as a form of participation and political deliberation. Amazonia Investiga, 9(27), 5-12. https://doi.org/10.34069/AI/2020.27.03.1

Arbeláez-Campillo, D., \& Rojas-Bahamon, M. (2020). Pandemics in globalization times. Amazonia Investiga, 9(27), 3-4. https://doi.org/10.34069/AI/2020.27.03.0

Blynova, O., Kisil, Z., Tkach, T., Semenova, N., Semenov, O., Kamisnka, S., \& Popovych, I. (2020a). Psychological manifestations of professional marginality of future social welfare professionals. Revista Inclusiones, 7(SI), 218-233. http://www.revistainclusiones.org/index.php /inclu/article/view/1229

Blynova, O., Lappo, V., Kalenchuk, V., Agarkov, O., Shramko, I., Lymarenko, L., \& Popovych, I. (2020b). Corporate Culture of a Higher Education Institution as a Factor in Forming Students' Professional Identity. Revista Inclusiones, 7(SI), 481-496. http://www.revistainclusiones.org/index.php /inclu/article/view/1305

Blynova, O., $\quad$ Moiseienko, V., $\quad$ Los, O., Burlakova, I., Yevdokimova, O., Toba, M., \& Popovych, I. (2020c). Assertiveness as a Factor of Students' Choice of Behavior Strategies in Social Interaction. Revista Inclusiones, 7(4), 259-272. http://www.revistainclusiones.org/index.php /inclu/article/view/1551

Blynova, O., Popovych, I., Semenova, N., Kashyrina, Ye., Ursulenko, O., \& Kononenko, O. (2020d). Personality Factors of Choosing Adaptation Strategies in a Different Cultural Environment by Labor Migrants from Ukraine. Revista Amazonia Investiga, 9(32), 45-54. Retrieved from http://dx.doi.org/10.34069/AI/2020.32.08.5

Halian, A., Halian, I., Burlakova, I., et al. (2020a). Emotional Intelligence in the Structure of Adaptation Process of Future Healthcare Professionals. Revista Inclusiones, 7(3), 447-460. http://www.revistainclusiones.org/index.php /inclu/article/view/1347

Halian, I., Machynska, N., Lozynska, S., et al. (2020b). Tolerance of uncertainty as a component of the process of life-creation of future educators. Revista Inclusiones, 7(SI), 512-528.

http://www.revistainclusiones.org/index.php /inclu/article/view/1307

Hudimova, A. Kh. (2021). Behavioral Patterns of Social Media Users as a Condition of Their Psychological Well-being. (PhD thesis) Odesa National I. I. Mechnikov University Online Repository. Retrieved from http://onu.edu.ua/pub/bank/userfiles/files/sci ence/razovi_spec_vcheni_rady/df41051014/ diss_GudimovaAH.pdf

Hudimova, A., Popovych, I., Baidyk, V., Buriak, O., \& Kechyk, O. (2021). The impact of social media on young web users' psychological well-being during the COVID19 pandemic progression. Revista Amazonia Investiga, $\quad$ 10(39), 50-61. https://doi.org/10.34069/AI/2021.39.03.5

Izard, C. E. (2007). Basic Emotions, Natural Kinds, Emotion Schemas, and a New Paradigm. Perspectives on Psychological Science, 2(3), 260-280. https://www.jstor.org/stable/40212206

Khanin, Yu. L. (1976). Scale D. Marlowe D. Crowne for studding approval motivation. Leninhrad: NIIFK. https://psytests.org/emotional/mcsds.html

Khmiliar, O., Popovych, I., Hrys, A., Pavliuk, M., Zavatska, N., Lytvynenko, O., \& Blynova, O. (2020). Spatial Regulation of Personality Behavior in the Conditions of Progression of the COVID-19 Pandemic. Revista Inclusiones, 7(SI), 289-306. http://www.revistainclusiones.org/index.php /inclu/article/view/1760

Kriukova, T. L., \& Kuftiak, Ye. V. (2007). The questionnaire of controlling (the adaptation of the methods WCQ). Journal of an applied 


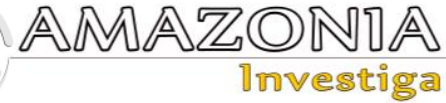

psychology specialist, 3(93), 102-112. Retrieved from https://www.twirpx.com/file/1656062/

Krupnyk, I. R., \& Tkalenko, N. V. (2019). Manipulative Behavior in the Professional Activities of Office Staff. Insight: the psychological dimensions of society, 1, 96-101. https://doi.org/10.32999/2663970X/2019-1-15

Lazarus, R. S., \& Folkman, S. (1984). Stress, appraisal, and coping. New-York: Springer Publishing

https://www.worldcat.org/title/stressappraisal-and-coping/oclc/609341596

Marcora, S. M., Staiano, W., \& Manning, V. (2009). Mental fatigue impairs physical performance in humans. Journal of Applied Physiology, 106(3), 857-864. https://doi.org/10.1152/japplphysiol.91324.2 008

Nosov, P., Palamarchuk, I., Zinchenko, S., Popovych, I., Nahrybelnyi, Y., \& Nosova, H. (2020a). Development of means for experimental identification of navigator attention in ergatic systems of maritime transport. Bulletin of the University of Karaganda - Physics, 1(97), 58-69. https://doi.org/10.31489/2020Ph1/58-69

Nosov, P.S., Zinchenko, S.M., Popovych, I.S., Ben, A.P., Nahrybelnyi, Y.A., \& Mateichuk, V.M. (2020b). Diagnostic system of perception of navigation danger when implementation complicated maneuvers. Radio Electronics, Computer Science, Control, 1, 146-161. https://doi.org/10.15588/1607-3274-2020-115

Pinkovetskaia, I., Arbeláez-Campillo, D., Rojas-Bahamón, M., \& Veas Iniesta, D. (2020). Motivation of new entrepreneurs in modern economies. Amazonia Investiga, 9(29),

368-373. https://doi.org/10.34069/AI/2020.29.05.41

Popovych, I., Arbeláez-Campillo, D. F., Rojas-Bahamón, M. J., Burlakova, I., Kobets, V., \& Bokshan, H. (2021a). Time perspective in the professional activity of specialists of economic sphere. Cuestiones Políticas, 39(69), 424-445. https://doi.org/10.46398/cuestpol.3969.27

Popovych, I., Chervinskyi, A., Kazibekova, V., Chervinska, I., \& Machynska, N. (2021b). Empirical research of the typology of social expectations of the personality. Amazonia Investiga, $\quad 10(43), \quad 112-122$ https://doi.org/10.34069/AI/2021.43.07.11

Popovych, I., Kononenko, O., Kononenko, A., et al. (2020a). Research of the Relationship between Existential Anxiety and the Sense of
Personality's Existence. Revista Inclusiones, 7(SI), 41-59. http://www.revistainclusiones.org/index.php /inclu/article/view/300

Popovych, I., Lymarenko, L., Tereshenko, N., Kornisheva, T., Yevdokimova, O., Koverznieva, A., \& Aleksieieva, M. (2020b). Research on the Effectiveness of Training Technologies' Implementation in Student Theater". Revista Inclusiones, 7(2), 104-121. http://www.revistainclusiones.org/index.php /inclu/article/view/261

Popovych, I., Shevchenko, A., Galvez, L. M., \& Klenina, K. (2021c). Research of the relationship between social desirability and value orientations of adolescents. Revista Notas Históricas y Geográficas, 26(1), 241268.

https://www.revistanotashistoricasygeografi cas.cl/index.php/nhyg/article/view/339

Popovych, I., Zhigarenko, I., Losiyevska, O., Dovbenko, S., Kashyrina, Ye., Shevchenko, R., \& Piletska, L. (2020c). Research of Achievement Motivation's Impaction the Career Orientations of Future Managers of Organization. Revista Inclusiones, $\quad 7(\mathrm{SI}), \quad$ 247-263. http://www.revistainclusiones.org/index.php /inclu/article/view/1231

Prokhorov, A. O., Chernov, A. V., \& Yusupov, M. G. (2015a). Cognitive states in educational activity of students: Structuralfunctional aspect. Asian Social Science, 11(1), 213-218. https://doi.org/10.5539/ass.v11n1p213

Prokhorov, A. O., Yusupov, M. G. \& Plokhikh, V. V. (2015b). Cognitive States in the Process of Students' Intellectual Activity. The New Educational Review, 41(3), 263-274.

https://doi.org/10.15804/tner.2015.41.3.21

Shevchenko, R., Cherniavskyi, V., Zinchenko, S., Palchynska, M., Bondarevich, S., Nosov, P., \& Popovych, I. (2020a). Research of psychophysiological features of response to stress situations by future sailors. Revista Inclusiones, 7(SI), 566-579.

http://www.revistainclusiones.org/index.php /inclu/article/view/1780

Shevchenko, R., Popovych, I., Spytska, L., Nosov, P., Zinchenko, S., Mateichuk, V., \& Blynova, O. (2020b). Comparative analysis of emotional personality traits of the students of maritime science majors caused by longterm staying at sea. Revista Inclusiones, $7(\mathrm{SI})$, 538-554. http://www.revistainclusiones.org/index.php /inclu/article/view/1309 
Spielberger, C. D. (1971). Notes and Comments Trait-State Anxiety and Motor Behavior. Journal of Motor Behavior, 3, 263-279. https://doi.org/10.1080/00222895.1971.1073 4907

Tomaszek, K., \& Muchacka-Cymerman, A. (2020). Thinking about My Existence during COVID-19, I Feel Anxiety and Awe - The Mediating Role of Existential Anxiety and Life Satisfaction on the Relationship between PTSD Symptoms and Post-Traumatic Growth. Int. J. Environ. Res. Public Health, 17 , 7062. https://doi.org/10.3390/ijerph17197062

Tsiuniak, O., Pyslar, A., Lialiuk, G., et al. (2020). Research of interdependence of variables and factor structure of masters' readiness for innovative pedagogical activity. Revista Inclusiones, 7(3), 427-452. http://www.revistainclusiones.org/index.php /inclu/article/view/1645
World Medical Association Declaration of Helsinki. (2013). Ethical principles for medical research involving human subjects, 310(20), 2191-4. https://doi.org/10.1001/jama.2013.281053

Zinchenko, S. M., Ben, A. P., Nosov, P. S., Popovych, I. S., Mamenko, P. P., \& Mateichuk, V. M. (2020). Improving the accuracy and reliability of automatic vessel moution control system. Radio Electronics, Computer Science, Control, 2, 183-195. https://doi.org/10.15588/1607-3274-2020-219

Zinchenko, S., Nosov, P., Mateichuk, V., Mamenko, P., Popovych, I., \& Grosheva, O. (2019). Automatic collision avoidance system with many targets, including maneuvering ones. Bulletin of University of Karaganda, 96(4), 69-79. https://physicsvestnik.ksu.kz/apart/2019-96-4/8.pdf 